\title{
製紙用タルク系ピッチコントロール剤
}

\author{
日本タルク株式会社 林順之助
}

\section{Talc as a Pitch Control Agent in the Paper Industry}

Junnosuke Hayashi

NIPPON TALC CO., LTD.

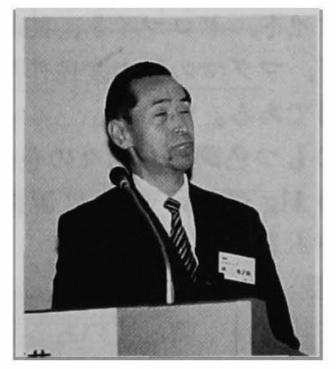

In the paper industry, the pitch removal technology is important. There are some methods for the pitch removal. In this report, the method using talc is described which is applied generally in the world. Molecular structure, morphology and basic properties of talc are indicated. And it is shown how to manufacture talc powders from raw material. This report also contains production quantity of talc in the world, import quantity to Japan, estimated consumption of talc in the world and Japan, and consumption of talc in the paper industry.

Talc is consumed in large quantities as a filler and a pitch control agent in the paper industry. The data of contact angle between talc and several liquids are quoted in connection with the pitch control ability of talc. Not all of the talc powders may be effective for the pitch control agent. Properties of talc are dependent on the production place of raw material and the condition of grinding by mill. Anyway it is indicated that the pitch control ability depends on the specific surface area of the talc.

\section{1.はじめに}

製紙工程において，ピッチの除去は重要課題である。 ピッチの除去方法として, 無機系, 有機系, 酵素系な どがある。無機系ではタルク使用が主であり，他にべ ントナイト系や合成マイカ系がある。また, 硫酸バン ドや他の製紙用添加剤を調整することにより，ピッチ によるトラブルを少なくしている。

本報では無機系の代表であるタルクについて，どん なものか, 原料産地や製造法, タルクの用途, 使用量, なぜピッチコントロール剤として使用されるか，また タルクの種類とピッチ吸着能との関係などについて紹 介する。

\section{2. タルクの概要}

タルクについての概要を表 1 に示す。タルクの構 造・形態写真を図 1 および図 2 に示す。

$\mathrm{SiO}$ 層と $\mathrm{SiO}$ 層との間は一次結合がなく, 弱い結合 しかないので，䢃開されやすく，板状形態となる。

\section{3. タルクの物性}

タルクの赤外吸収スペクトルを図 3 に, 示差熱特性 を図 4 に示す。タルクのX線回折図を图 5 に示す。以 上は典型的なタルクについてのデータである。

現実のタルクは表 2 に示すように，種々の成分を含 んでいる。製紙分野で使用される数種の夕ルクのX線 回折図を図6 8に示す。図 6 がピッチコントロール用 に使用されているタルクの例である。 
表 1 タルクの概要

化学組成は, 含水珠酸マグネシウム $\left(\mathrm{Mg}_{2} \mathrm{Si}_{4} \mathrm{O}_{10}\right.$ $(\mathrm{OH})_{2}$ or $\left.3 \mathrm{MgO} \cdot 4 \mathrm{SiO}_{2} \cdot \mathrm{H}_{2} \mathrm{O}\right)$ で表され, 理論的 組成値は， $\mathrm{SiO}_{2} 63.5 \%, \mathrm{MgO} 31.7 \%$, Ig. Loss $4.8 \%$, 真比重 2.7 2.8，モ一ス硬度 1.0 である。 天産品の通例として純粋なものは無く，酸化鉄や アルミナ等を多少含んでいる。原鉱石は淡紅色， 白色，淡緑色，灰色などをしている。

マグネサイト，ドロマイト，蛇紋岩，緑泥岩を母 岩として, マグマの熱水変性作用によって生成し た変性岩である。

原鉱石のもつ色調は, 元々の色は白色であるが, 成分中の $\mathrm{Mg}$ が $\mathrm{Mn}$ や $\mathrm{Fe}$ に置換されると着色す ることがある。

（主な特徴）

(1)極めて軟らかく潤滑性のある顔料・充填材であ る。

(2)電気絶緑性に優れる。

(3)化学的に安定している。即ち耐アルカリ性, 耐 酸性に優れている。

タルク、湆石（含水䀧マサネシウム）

$3 \mathrm{MgO} \cdot 4 \mathrm{~S}$ i O $: \mathrm{H}_{2} \mathrm{O}$
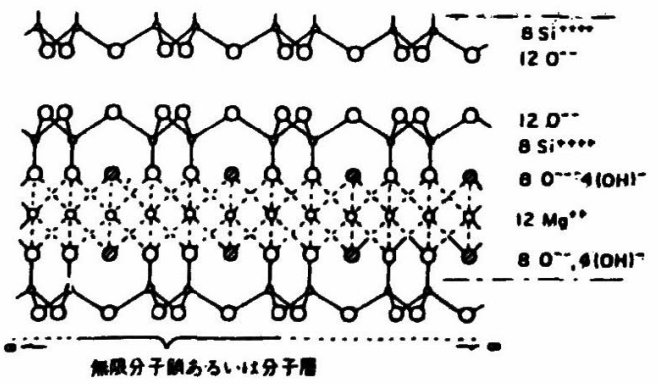

図 1 純粋なタルク鉱物の分子構造

\section{4. タルクの生産}

タルクの製造工程の概略は图9の通りである。世界 の主な滑石産出国と日本の年生産量を表 3 に示す。国 産原料の品質はあまり良くない。

タルク原料輸入量を表 4 に示す。中国品とオースト ラリア品が主である。

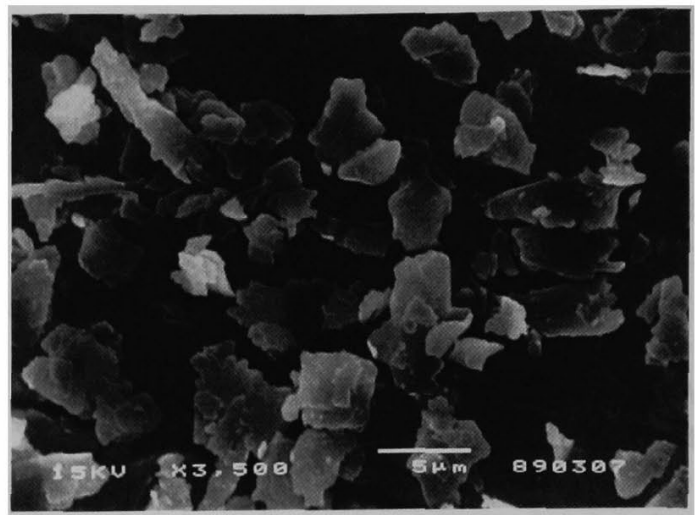

図 2 タルクの顕微鏡写真

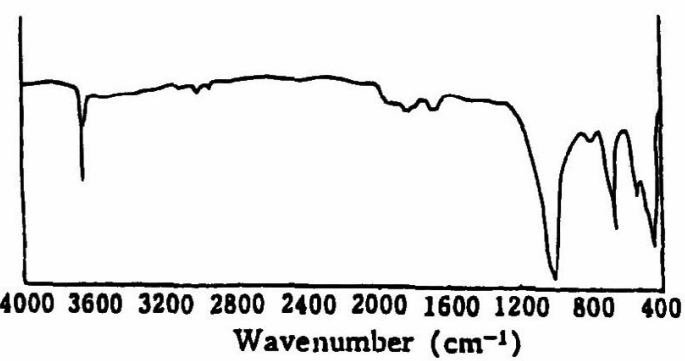

図 3 FTIR spectra of TALC

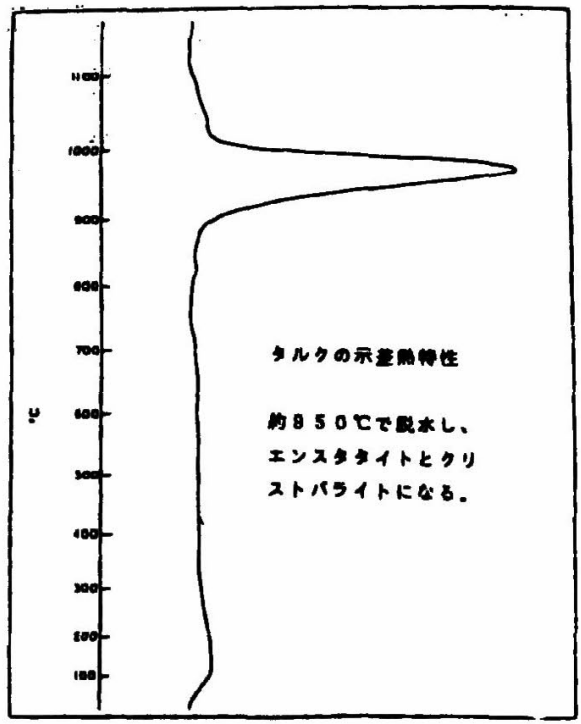

図 4 タルクの示差熱特性 
製紙用タルク系ピッチュントロール剂

表 2 輸入及び国産タルクの組成（例）

\begin{tabular}{|c|c|c|c|}
\hline 産 & 地 & 主 成 分 & 副＼cjkstart成 \\
\hline 中国 & $\begin{array}{l}\text { 遼寧省 } 1 \\
\\
\end{array}$ & $\begin{array}{l}\text { タルク } \\
\text { タルク, クロライト }\end{array}$ & $\begin{array}{l}\text { マグネサイト, ドロマイト } \\
\text { マグネサイト, ドロマイト }\end{array}$ \\
\hline & 山東省 & タルク, クロライト & マグネサイト, ドロマイト \\
\hline & 広西 & タルク & クロライト, ドロマイト \\
\hline 豪州 & & タルク & クロライト, ドロマイト \\
\hline 米国 & & タルク & ドロマイト \\
\hline 日本 & & タルク & $\begin{array}{l}\text { マグネサイト, クロライト } \\
\text { ドロマイト }\end{array}$ \\
\hline
\end{tabular}

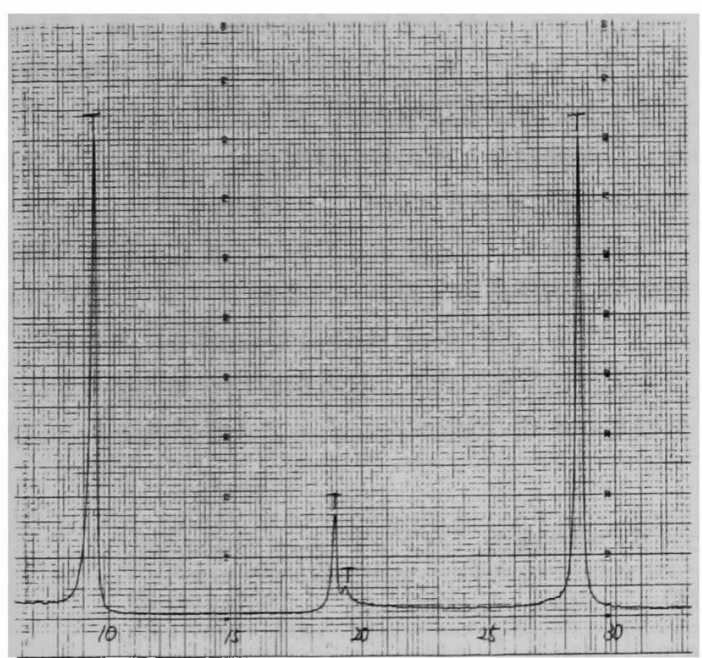

図 5 タルクのX線回折図 (1)

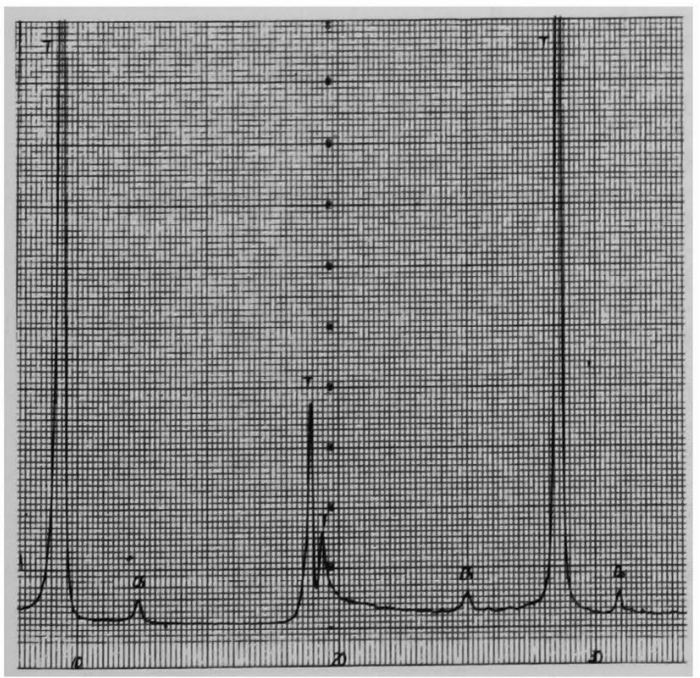

図 6 タルクのX線回折図（2）

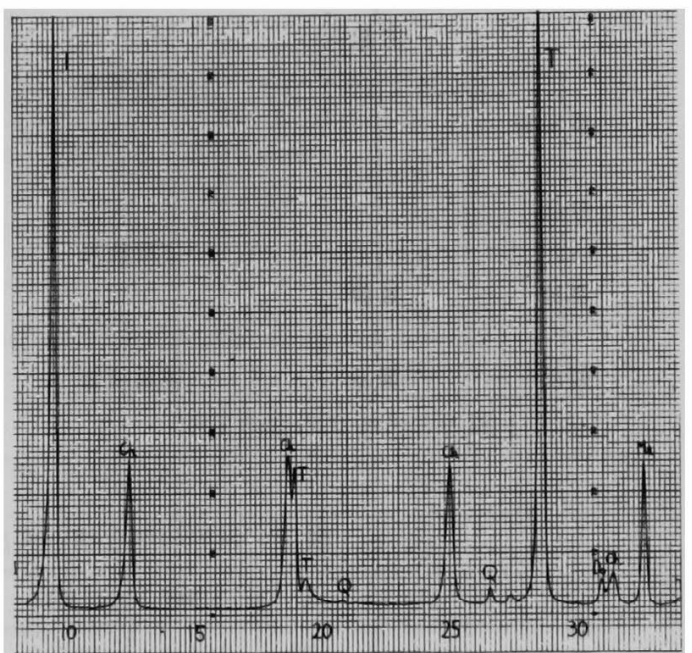

図 7 タルクのX線回折図（3）

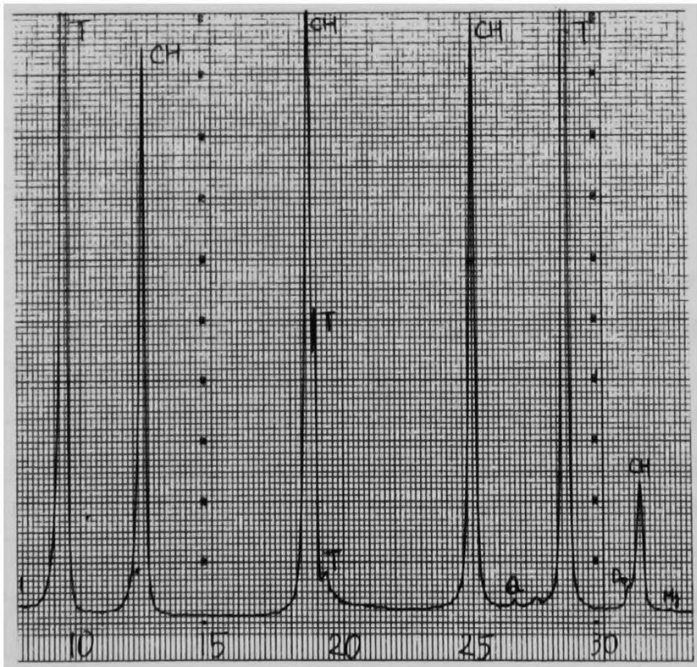

図 8 タルクのX線回折図（4） 


\section{5. タルクの用途}

世界におけるタルクの用途と, 地域別・用途別使用 量を表 5 に示す。日本における用途別使用量・比率の 推定値を表 6 に示す。製紙用が主であり樹脂用や塗料 用も多い。製紙分野においてタルクは，カオリンや炭

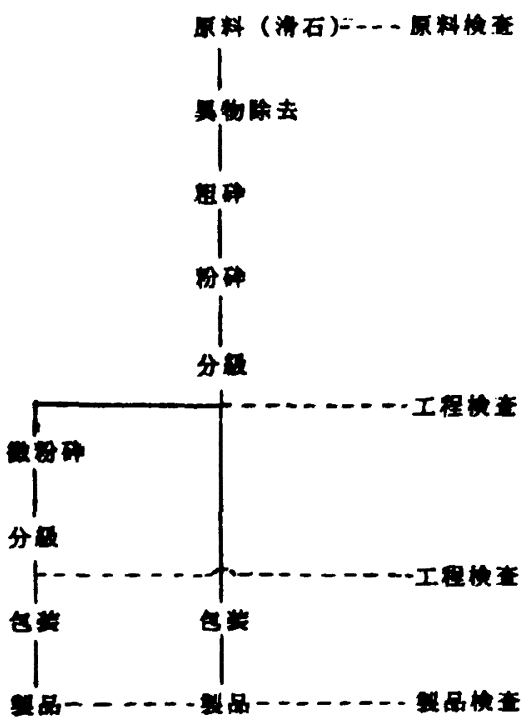

図 9 タルクの製造工程
酸カルシウムに次いで，使用量が多い。

製紙分野におけるタルクの使用分野は内填郕, ピッ 千吸着㧩，コーティング剂に分類される（表 7，表 8)。 アジアにおけるタルクのピッチ吸着郕への使用比率は 低いが, 最近の日本における使用此率はもっと大きい と推定される。

\section{6. 脱ピッチ剤としてのタルクの利用}

\section{1 タルクの特性}

タルクの特性と紙の特性との関係を表 9 に示す。 ピッチ吸着能に関係するのは, 粒子の大きさ, 比表面

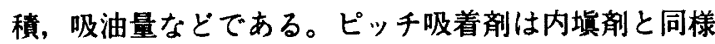
に製紙工程で添加されるため, 白色度, 粒子の形, 硬 さ，化学的安定性なども重要となる。

次に，タルクがなぜピッチ吸着郕として適している かについて示す。表 10 に示されるように，各種の物質 のタルクに対する接触角は, 水・クリセロール・アニ リンなど表面張力の大きい物質を除いて，いずれも 0 である。接触角が 0 ということは儒れやすいこと,従っ て吸着しやすいことを示している。また，DIPの粘着 性成分に関係あると思われる醀酸ビニルや SBR ゴム についても，SP (Solubility Parameter) から見て, 芳香族炭化水素に近く，接着剤や粘着郕に使用される 酢酸ビニルや SBR コムムもタルクと親和性があること

表 3 世界の主な滑石産出国と日本の年生産量（万トン）

\begin{tabular}{|c|c|c|c|c|c|}
\hline & 1988 & 1989 & 1990 & 1991 & 1992 \\
\hline 国 & 163.0 & 205.0 & 220.0 & 230.0 & 265.0 \\
\hline 国 & 113.6 & 117.2 & 118.5 & 103.7 & 99.7 \\
\hline イント & 41.8 & 41.4 & 39.0 & 40.0 & 42.5 \\
\hline 口 $\quad$ $T$ & 53.0 & 53.0 & 50.0 & 45.0 & 40.0 \\
\hline フィンランド & 37.9 & 39.8 & 38.5 & 37.5 & 35.0 \\
\hline フランス & 32.0 & 33.0 & 28.4 & 30.0 & 30.0 \\
\hline フラジル & 37.9 & 43.3 & 33.0 & 33.0 & 29.3 \\
\hline 州 & 20.2 & 20.9 & 23.5 & 17.4 & 21.0 \\
\hline 北 朝 鮮 & 17.0 & 17.0 & 17.0 & 17.0 & 17.0 \\
\hline 国 & 14.7 & 16.2 & 18.2 & 18.0 & 16.0 \\
\hline 本 & 5.0 & 5.6 & 6.2 & 6.6 & 5.9 \\
\hline そ の 他 & 90.6 & 87.9 & 86.6 & 86.5 & 82.9 \\
\hline 合 計 & 626.7 & 680.3 & 678.9 & 664.7 & 684.3 \\
\hline
\end{tabular}

北原：エネルギー・资源，15，(6) 67 (94).

$\begin{array}{r}\frac{1997}{250} \\ \hline 99 \\ \hline 37 \\ \hline 40 \\ \hline 40 \\ \hline 35 \\ \hline 25 \\ \hline 23 \\ \hline 17 \\ \hline 3 \\ \hline 654 \\ \hline\end{array}$


表 4 タルク原料輸入量

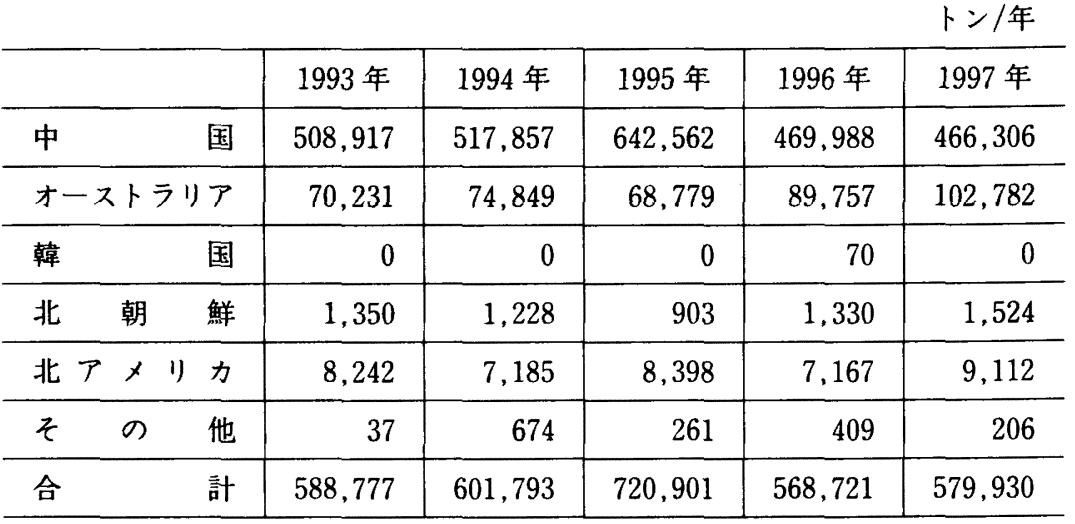

大蔵省関税局統計

表 5 Estimated consumption of talc products by end-use, 1994 ('000 s tonnes)

\begin{tabular}{l|c|c|c|c|c|c|r}
\hline Application & $\begin{array}{l}\text { North } \\
\text { America }\end{array}$ & $\begin{array}{l}\text { South } \\
\text { America }\end{array}$ & $\begin{array}{l}\text { Western } \\
\text { Europe }\end{array}$ & $\begin{array}{l}\text { Eastern } \\
\text { Europe }\end{array}$ & $\begin{array}{l}\text { Africa \& } \\
\text { Oceania }\end{array}$ & Asia & Total \\
\hline Paper & 150 & 100 & 375 & 300 & 20 & 1,800 & 2,745 \\
\hline Plastics & 65 & 30 & 150 & 50 & 15 & 280 & 590 \\
\hline Paint & 150 & 50 & 140 & 50 & 5 & 150 & 545 \\
\hline Ceramics & 265 & 470 & 75 & 60 & 10 & 475 & 1,355 \\
\hline Cosmetics & 45 & 10 & 30 & 10 & 2 & 25 & 122 \\
\hline Agrochemicals & 13 & 10 & 30 & 20 & 3 & 45 & 121 \\
\hline Roofing & 60 & 55 & 80 & 65 & 6 & 85 & 351 \\
\hline Other & 117 & 50 & 105 & 35 & 4 & 270 & 531 \\
\hline Total & 865 & 775 & 985 & 590 & 85 & 3,130 & 6,410 \\
\hline
\end{tabular}

Industrial Minerals, May 1997

表 6 タルクの用途別使用量（推定）

1997 年国内

\begin{tabular}{|c|c|c|c|}
\hline 用 & 途 & $\begin{array}{c}\text { 概 数 } \\
ト \text { ト / 年 }\end{array}$ & $\begin{array}{c}\text { 比 } \\
\%\end{array}$ \\
\hline 製 & 紙 & 384,000 & 60 \\
\hline 樹 & 脂 & 128,000 & 20 \\
\hline 塗 & 料 & 90,000 & 14 \\
\hline そ $の$ & 他 & 38,000 & 6 \\
\hline 合 & 計 & 640,000 & 100 \\
\hline
\end{tabular}

を示している(図10)。

\section{2 タルクの品筑}

タルクはピッチ吸着剤として適しているが，全ての タルクが同程度に効果があるのではない。タルクの種 類により, 効果が異なる。その要因を表 11 に示す。

タルクの産地により，成分・純度が異なり，ピッチ 吸着能も異なる。また同し原料であっても, 粉碎の程 度により平均粒子径が異なり, 此表面積や吸油量が異 なる。また製造条件により，平均粒子径が同しでも比 表面積の異なるタルクが得られる。タルク表面をカチ オン化することにより, 吸着力を改善するとの報告も ある。 


林_順之助

表 7 製紙分野での消費量

\begin{tabular}{c|cc|c|c|c|c}
\multicolumn{10}{c|}{} & 1993 年 & 1994 年 & 1995 年 & 1996 年 & 1997 年 \\
\hline タ ル ク & 358,134 & 353,051 & 383,656 & 390,778 & 384,070 \\
\hline 炭酸カルシウム & 444,316 & 451,906 & 484,574 & 521,243 & 504,040 \\
\hline カオ リ ン & 675,963 & 694,096 & 741,253 & 745,115 & 757,850 \\
\hline
\end{tabular}

通産省統計

表 8 タルクの紙分野への応用

\begin{tabular}{|c|c|c|c|}
\hline & $\begin{array}{c}\text { ヨーロッパ } \\
1990\end{array}$ & $\begin{array}{c}\text { アジア } \\
1989\end{array}$ & $\begin{array}{c}\text { アメリカ } \\
1989\end{array}$ \\
\hline 内填剂* & 300,000 & 850,000 & 5,000 \\
\hline ピッチ吸着剂** & 165,000 & 100,000 & 140,000 \\
\hline コーティング剂*** & 90,000 & 0 & 0 \\
\hline
\end{tabular}

T. BAAK, G, J. GILL, PAPER OCH TRA, NO 8,449 (1991)

*内填郕：白色度, 磨耗度, 平滑性, 吸油性, 印刷特性

**ピッ千吸着剂：比表面穔，吸油性

***コーティング剂：平滑性, 粘度, 水への分散

表 9 紙分野におけるタルク特性

\begin{tabular}{|c|c|}
\hline 1)白さ & 色 \\
\hline 2)粒子の大きさ & :ピッチ吸着能，摩耗度 \\
\hline 3)粒子の形 & ：平滑性 \\
\hline 4)粒子の硬さ & 摩耗度 \\
\hline 5)化学反応性 & ：酸性紙，中性紙 \\
\hline 6)粒子の比表面積, 吸油量 & :ピッチ吸着能, 印刷特性 \\
\hline 7) 䧮蔽力, 届折率 & : S 值, 不透明度 \\
\hline 8)比重 & 坪量 \\
\hline
\end{tabular}

次にピッチ吸着能の評洒方法を表 12 に示す。ピッチ 数を顕微鏡で観察しカウントするへマストメーター法, ピッチを溶郕で抽出して効果を比較する方法, ピッチ の色や濁度を比較する吸光度法などがあるが，モデル サンプルについての実験方法としては吸光度法が適し ている。

産地の異なる各種タルクについて，同条件で実機粉 碎したものからサンプリンクして，人工ピッチに添加 し十分に接触させた後，滤過した液について透過率を 比較することにより (吸光度法) タルクのピッチ吸着
能を比較した。その結果を図 11 に示す。

図11のサンプルについて,タルクのレーザー回折法 による平均粒子径 $\mathrm{D}_{\mathrm{s} 0}$ と BET 法による比表面積との 関係を図 12 に示す。平均粒子径が小さいもの程, 当然 比表面稓は大きい。この傾向は産地により二分される ようである。この差の原因は明らかではない。実用的 には、このデータ以外に粉碎効率の差も重要である。 次に図 12 の比表面積值とピッ千吸着能との関係を プロットしたのか図13である。四12では二分される ようであるが, 図13では一部のデー夕を除いて、ほほ 1 本の曲線で近似されるようである。即ち，タルクの ピッチ吸着能は主として比表面䅪により決まるようで ある。なお,本データでは比表面積の大きい領域でピッ 千吸着能（透過率）が頭打ちになっているが,これは 実験条件の設定が必ずしも適切でなかったことによる。 次に，同し原料を用いて，彆造条件を变更した場合 のデータ比較を示す。彆造条件 A，B，Cで平均粒子径 を変化させたものについて，平均粒子径 $\mathrm{D}_{50}$ と比表面 稓との関係を図 14 に示す。平均粒子径が同じでも，製 造条件により比表面稓の異なるタルクを得ることがで きる。図14に他社品についても，比較のためプロット 
整就用タルク柔ピッチコントロール郕

表 10 Contact angles on talc $\left(25^{\circ} \mathrm{C}\right)$

\begin{tabular}{clcc}
\hline & Liquid & $\begin{array}{c}\text { Surface tensions } \\
\text { dynes } \mathrm{cm}^{-1}\end{array}$ & Contact angle \\
& water & 72.8 & $88^{\circ}$ \\
& methanol & 26.6 & 0 \\
& ethanol & 22.3 & 0 \\
& propanol & - & 0 \\
& amyl alcohol & 25.7 & 0 \\
& glycerol & 63.4 & 56 \\
& formic acid & 37.6 & 22 \\
& acetic acid & 27.6 & 0 \\
& benzene & 28.9 & 0 \\
& toluene & 28.5 & 0 \\
& cyclohexane & 25.5 & 0 \\
triethylamine & - & 0 \\
compo- & aniline & 44.1 & 40 \\
nents & $\left\{\begin{array}{l}\text { tall oils } \\
\text { D-limonene }\end{array}\right.$ & $32.5-35.8$ & 0 \\
& D-pinene & - & 0 \\
bornyl acetate & - & 0 \\
& mercury & 484 & 0 \\
\hline
\end{tabular}

W. SCHOBER, PULP\&PAPER, MAY, 117 (1991)

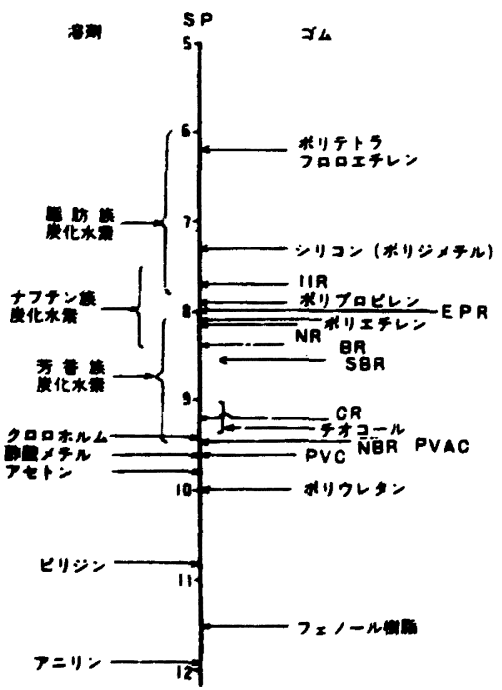

图 10 溶剂とコム高分子の SP の関係
表 11 タルクのピッチ吸着能についての要因

1. 産地, 純度

2. 比表面積 ·吸油量

平均粒子径

細孔分布

製造条件
表 12 ピッチ吸着能の評価方法

1. ヘマストメーター法

ピッチ数を顕微鏡で観察しカウント

2. 吸光度法

着色ピッチについて，色の溇さで比較

3. 溶剂抽出法

吸着ピッチを溶剤で抽出して重量比較

4. 紙面の污点をカウント

5. その他 


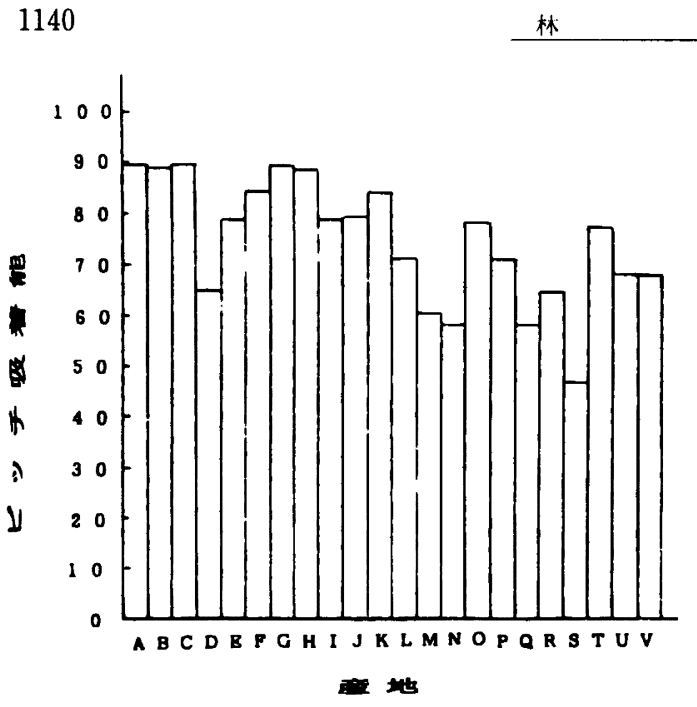

図 11 タルクの産地とピッチ吸着能

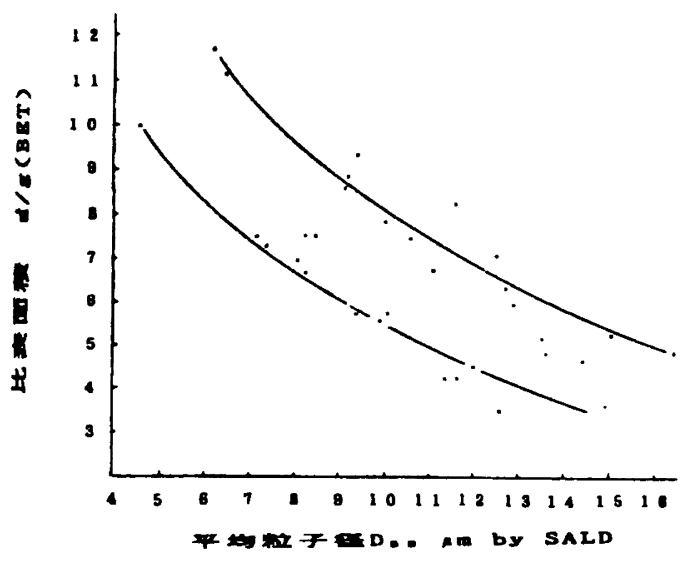

图 12 平均粒子径と比表面積 (タルク原料産地比較)

した。

图 14 のサンプルについて, 比表面積と吸光度法によ るピッチ吸着能比との関係を図 15 にプロットした。先 の困 13 と同様にピッチ吸着能は主としてタルクの比 表面積により決まるようである。

以上のようにタルクのピッチ吸着能は, タルクの原 料産地や製造条件の違いによる平均粒子径や, 特に比 表面程により，決まるようである。䔩社は，これらの 要因および製造条件とコストならびにユーザーニーズ を考虑しつつ, ピッチコントロール用タルクの改善・ 開発を進めている。
順之助

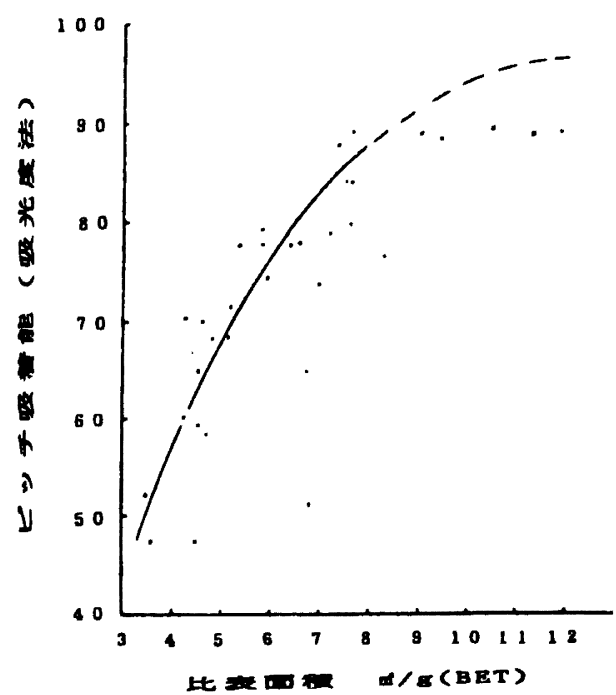

図 13 比表面積とピッチ吸着能 (吸光度法)

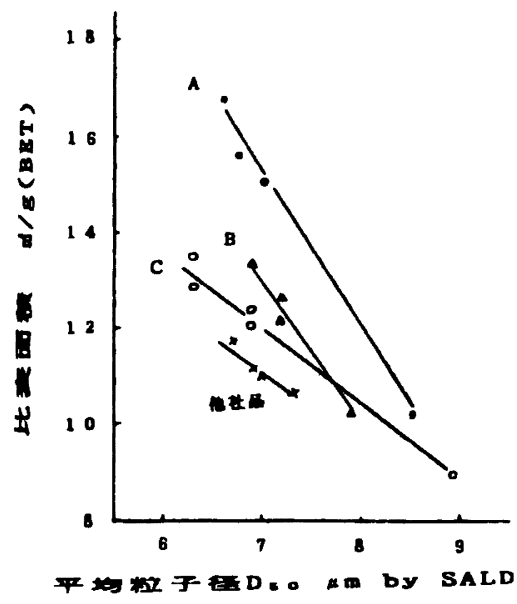

図 14 平均粒子径と比表面積

（製造条件による相違）

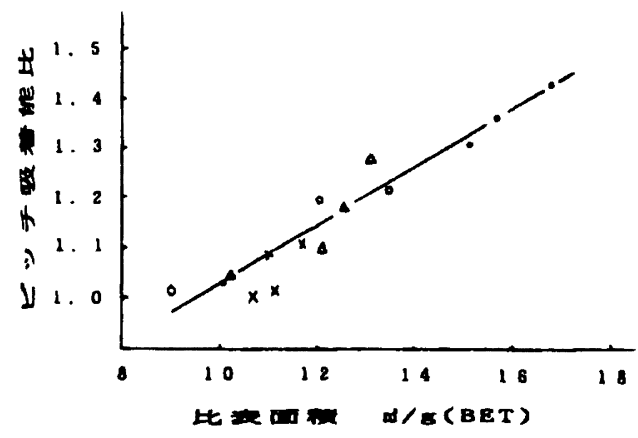

図 15 比表面積とピッ千吸着能比 (吸光度法) 


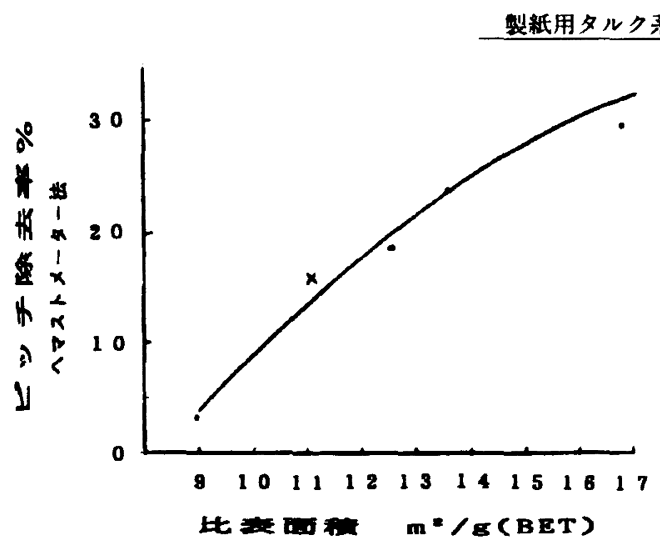

図 16 新聞系 DIP でのピッチ吸着

なお，製造工程におけるピッチトラブルは KP 系よ りも，DIP 系において問題になっている。即ち古紙を 使用する場合, 粘着テープからの粘着物や, 本の背貼 クからのホットメルト接着郕（温度の高い工程で容易 に軟化する）などが製紙工程中で粘着性物質としてト ラブルの元になっている。このような粘着物の大きい ものは, 通常機械的にスクリーンなどで分離されてい る。

一方，これらの粘着物質が徽細な状態で分散してお れば, 従来のパルプ液中のピッチと同様に、ピッチ吸 着棛により除去できることが期待される。先ず新聞系 DIPについて，比表面積の異なるタルクによると゚ッチ 除去率をへマストメーター法で調へた結果を図 16 に 示す。先と同様にタルクの比表面稹が大きい程, 除去 率が高いことを示している。

次に粘着性物質のモデルとして, SBR ゴムラテック スと酢酸ピニルエマルジョンについて，タルクによる 吸着・除去テストを行った。タルクにより，ラテック スやエマルションの渴度が小さくなる。即ち透過率が

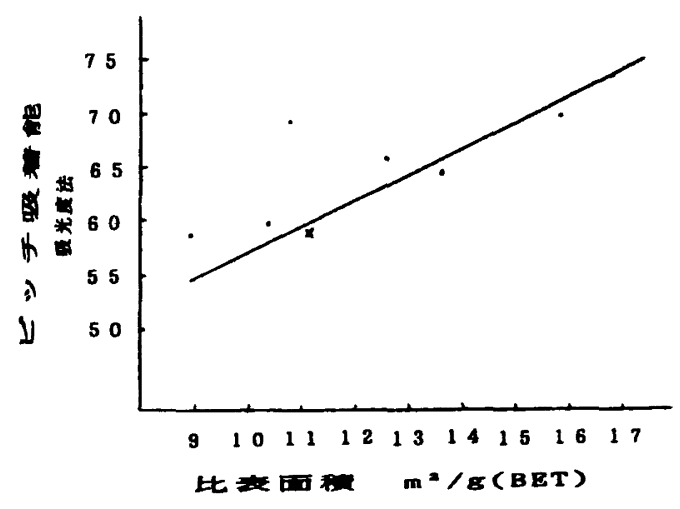

图 17 SBRラテックス采

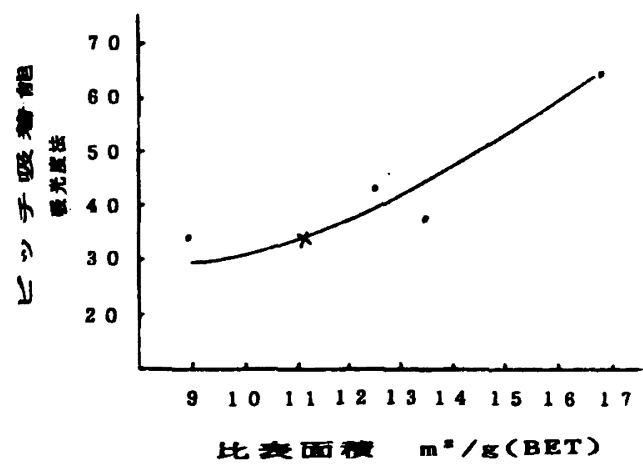

図 18 酢酸ビニルエマルジョン系

大きくなる。この結果を図 17, 18 に示す。

SBR ラテックスや酢酸ビニルエマルジョンにおい ても，ポリマーの微細な粒子（ピッチ）がタルクによ り吸着・除去されることがわかる。またこの場合も タルクの比表面穔に依存している。

以上,タルクによるピッチ吸着効果について説明し てきたが、参考にしていなだきたい。 


\section{般 文 概 要一筌}

\section{製紙用タルク系ピッチコントロール剤}

日本タルク株式会社 林 順之助

製紙工程において,ピッチの除去は重要課題である。ピッチの除去方法として各種の方法があるが, 本 報では広く一般的に利用されているタルクによるピッチ除去について記述する。

先ずタルクとはどんなものか。分子構造，形態，基本特性および一般特性などを示した。原料の滑石か ら粉体タルクの製造法の概略も示した。世界における原料滑石の産出量, 日本への輸入量, 世界および日 本における用途別使用量を示した。製紙工業においてタルクは内填剤として，またピッチコントロール绪 他として多量に使用されている。

ピッチコントロール性能に関連し，タルクと各種物質との接触角データを引用した。なお，全てのタル クがピッチコントロール郕として有効とは限らない。タルク原料の産地との関係,また製造条件によって 異なることを示した。いずれにせよピッチ吸着能はタルクの比表面稓に依存していることを示した。

(本文 31 ページ)

\section{有機系ピッチコントロール剤『MRT シリーズ』}

\section{株式会社日新化学研究所 中岛 克明}

ピッチを構成する成分は, 工程全般にわたって存在しており，最初は無害な状態にあったものが, ある 種の条件下で結合し集塊化することによりピッチトラブルを引き起こす。

ピッチコントロール刻は, ピッチ粒子の表面に作用する界面化学的アプローチであり, 各種の界面活性 剂が用いられている。製紙工業に於いても，多くの各種界面活性剂が使用されているため，電荷による挙 動を良く理解し，適切に処理することが，ピッ千問題を解くカキとなる。

有機系ピッチコントロール剂は, 分散, 溶解夕イプから吸着タイプの考え方にかわりつつあり, 添加方 法についても内添から外添にかわってきている。しかし, 古紙の再利用, 白水のクローズド化に伴いピッ チの粘着性を低下させた状態で紙に抄き込むことが最も重要なことと考え MRTシリーズを開発した。 MRT シリースの最大の特徽は、ステアリン酸要鉛を特殊カチオン界面活性剤で, 微粒子の状態に分散し たエマルジョンである。MRT シリーズの使用により，ピッチ粘着性軽隇奻果，異物鿵蔽性効果等，様々 な効果をもたらす。

(本文 40 ページ)

\section{酥素による紙パルプ製造エ程のピッチコントロール}

\section{ノホノルティスクパイオインタストリー株式会社 応用技術部 下戸 秀㮩}

日本製紙株式会社（当時十条製紙株式会社）が,リパーゼによるピッチコントロールについて発表し てから今年で 10 年になる。この間日本彆紙を始め, 各社の工堨でリパーゼによるピッチコントロール が導入されている。

本講演では、リパーセ（商品名，レジナーセＡ２X) を使用した GP (Groundwood Pulp) 及び TMP (Thermo Mechanical Pulp) 製造ラインで，ピッチコントロールの工場実験を行った例を紹介した。従 来からリパーゼか使用されている GP 製造工程だけではなく，TMP 製造工程での効果が確認されたこ 